\title{
Protozoan parasites in cultured mussels Mytilus galloprovincialis in the Thermaikos Gulf (north Aegean Sea, Greece)
}

\author{
Abdalnasser Rayyan, Panagiotis Damianidis, Chryssanthi Antoniadou, \\ Chariton C. Chintiroglou*
}

Department of Zoology, School of Biology, Aristotle University of Thessaloniki, PO Box 134, 54006 Thessaloniki, Greece

\begin{abstract}
The protozoans Ancistrum mytili (Oligohymenophorea: Ancistridae) and Marteilia refringens/maurini (Marteiliidea: Marteiliidae) were found parasitizing cultured mussels Mytilus galloprovincialis L. in the Thermaikos Gulf (north Aegean Sea, Greece). The former did not affect the condition index of infected mussels, in contrast to the latter, which did so and which also induced hemocyte infiltration in the affected digestive epithelium. The prevalence of both parasites was relatively high in a polluted area.
\end{abstract}

KEY WORDS: Ancistrum mytili $\cdot$ Marteilia refringens/maurini $\cdot$ Mytilus galloprovincialis $\cdot$ Mussel pathogens Resale or republication not permitted without written consent of the publisher

\section{INTRODUCTION}

Farming of mussels Mytilus galloprovincialis L. constitutes a very important industry in the Thermaikos Gulf (north Aegean Sea, Greece). As a result, the occurrence of a diminished harvest and a weakened mussel condition made it necessary to conduct an investigation into the probable causes (Arsenoudi et al. 2003). The first investigation reported on the impact of Steinhausia mytilovum on mussels (Rayyan \& Chintiroglou 2003). The present study focuses on 2 additional protistans, Ancistrum mytili and Marteilia refringens/maurini, which infect the gills and the digestive tubules of the mussels, respectively. The ciliate $A$. mytili has a wide geographical range, affecting mussels from the Atlantic and Pacific coasts of the USA, NW Spain, and Italy (Lauckner 1983, Da-Ros \& Massignan 1985, Robledo et al. 1994, Villalba et al. 1997). M. refringens/maurini, a combined name suggested to overcome diagnostic challenges (Villalba et al. 1993, Bower et al. 1994), occurs along the Atlantic coast of Europe and in many localities in the Mediterranean Sea (Comps et al. 1982, Ceschia et al. 1992, Vil- lalba et al. 1993, Fuentes et al. 2002). The study herein focuses on the occurrence of both parasites, as well as the prevalence in and effects on the mussel host.

\section{MATERIALS AND METHODS}

In total, 294 individuals of Mytilus galloprovincialis were collected from 'long-line' mussel cultures in 3 localities in the Thermaikos Gulf (north Aegean Sea, Greece), i.e. 98 individuals from each station: Makrygialos (Stn 1), Halastra (Stn 2), and Nea Michaniona (Stn 3) (Fig. 1). The mussels were 5 to $9 \mathrm{~cm}$ in shell length. After collection, the mussels were cleaned of mud and biofouling organisms, measured, and shucked. The condition index (CI) was calculated from total wet weight (TW), wet meat weight (MW), and shell weight (SW) based on the formula:

$$
\mathrm{CI}=[\mathrm{MW} /(\mathrm{TW}-\mathrm{SW})] \times 100(\text { Aguirre 1979) }
$$

Pieces of gills and digestive tubule were processed for histology following standard protocols (Martoja \& 


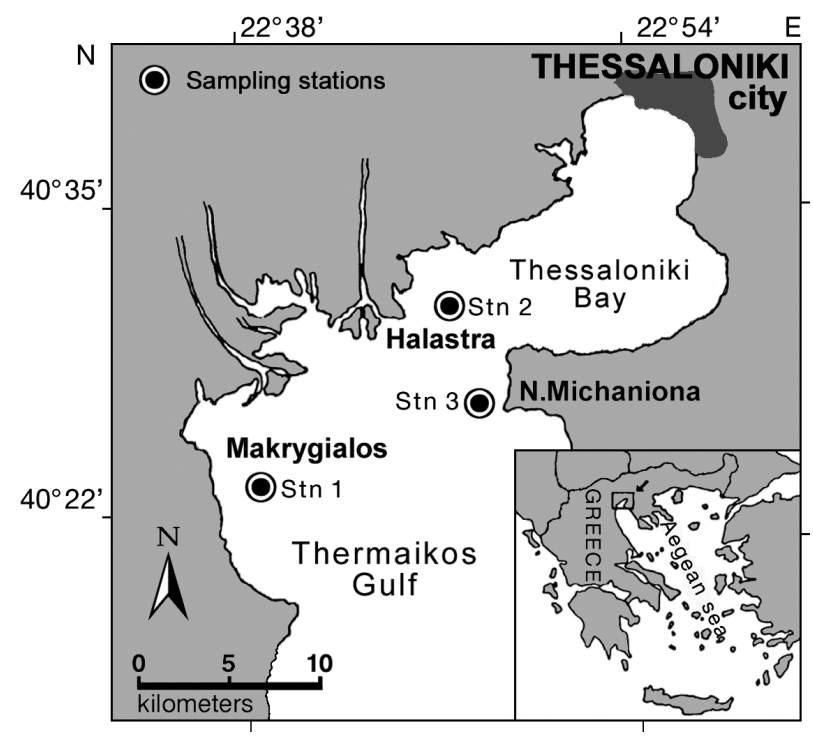

Fig. 1. Sampling stations in the Thermaikos Gulf (north Aegean Sea, Greece)

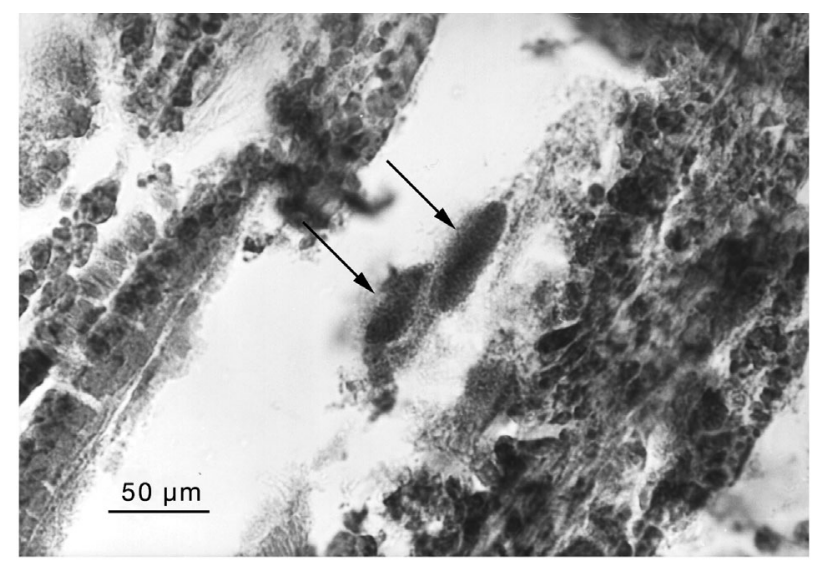

Fig. 2. Mytilus galloprovincialis. Ancistrum mytili infection (arrows) on the gills

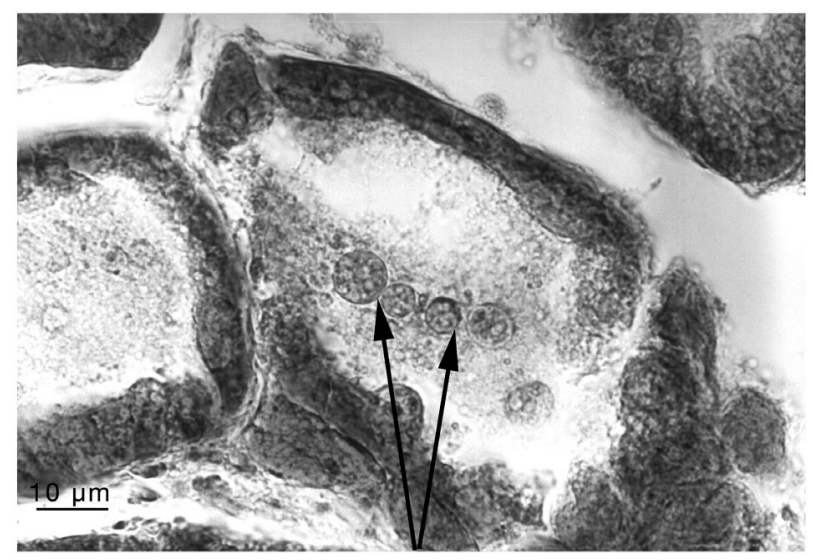

Fig. 3. Mytilus galloprovincialis. Various developmental stages (arrows) of Marteilia refrigens/maurini in the digestive lumen
Martoja 1967). Mussels were then placed in $10 \%$ buffered formalin.

One-way ANOVA was used to compare the CI of infected and non-infected mussels.

\section{RESULTS}

\section{Description}

Cells of Ancistrum mytili (Oligohymenophorea: Ancistridae) were observed moving freely over the gill filaments of the mussels (Fig. 2). The cells were 32 to $57 \mu \mathrm{m}$ in length, each containing 2 nuclei. Various developmental stages (plasmodia, primary, and secondary cells) of Marteilia refringens/maurini (Marteiliidea: Marteiliidae) were detected in the digestive tubules of the host (Fig. 3).

\section{Impact on the host}

There were no visible lesions on the tissues in association with the presence of the ciliate Ancistrum mytili. There was also no significant difference in the CI of infected and non-infected mussels (Fig. 4, 1-way ANOVA, $F$-ratio $=1.68 ;$ p-value $=0.1955$ ) .

Marteilia refringens/maurini infected the digestive tubules of the mussels, resulting in a significant difference in the $\mathrm{CI}$ of infected and non-infected mussels (Fig. 5, 1-way ANOVA, F-ratio = 12.06; p-value < $0.0001)$.

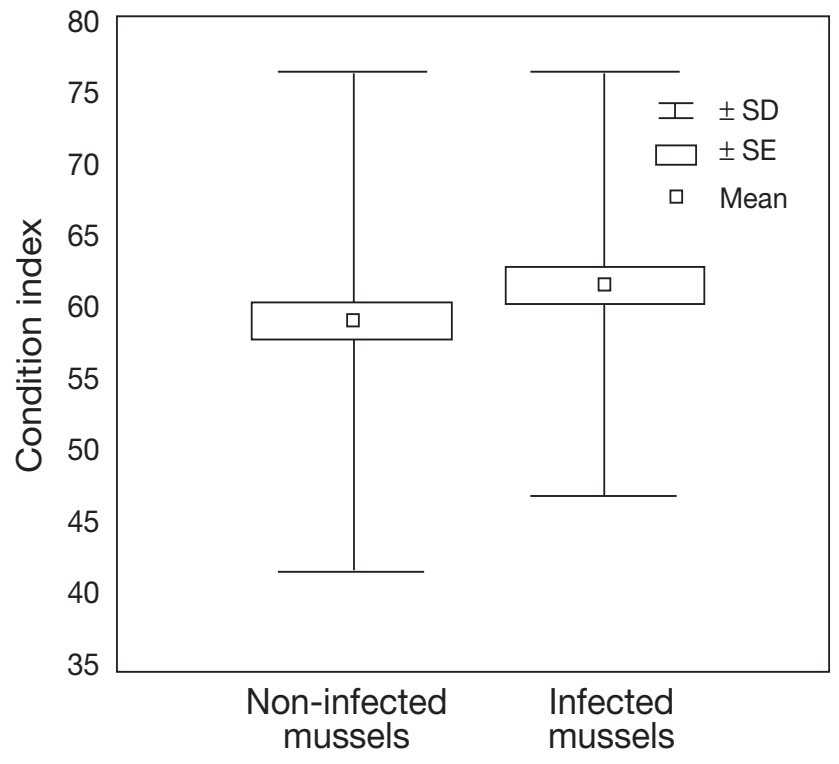

Fig. 4. Mytilus galloprovincialis. Condition index of mussels infected by Ancistrum mytili, and of non-infected mussels 


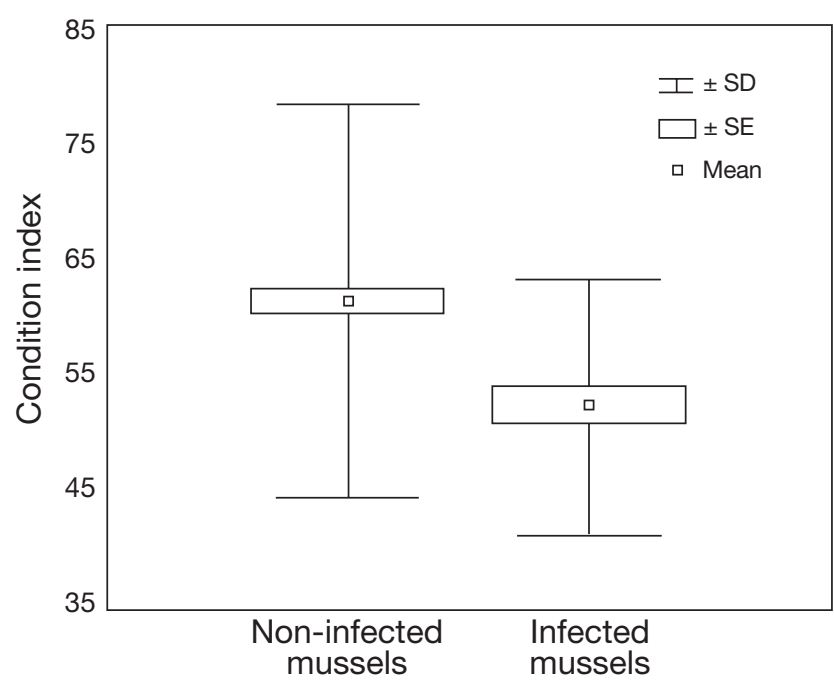

Fig. 5. Mytilus galloprovincialis. Condition index of mussels infected by Marteilia refrigens/maurini, and of non-infected mussels

\section{Prevalence of the parasites}

Among the 294 mussels examined from the 3 stations, $109(37.1 \%)$ were infested with the ciliate Ancistrum mytili. The prevalence of $46.9 \%$ among the mussels from the polluted area (Halastra) was higher than the prevalence of the parasite at the other 2 stations $(31.6 \%$ at Stn 1 and $32.6 \%$ at Stn 3$)$, which are further from sources of pollution. In contrast, only 43 mussels $(14.6 \%)$ were infected with Marteilia refringens/maurini. The prevalence of this parasite was again higher in mussels from the polluted area $(24.5 \%)$ than at the other 2 stations $(12.2 \%$ at Stn 1 and $7.1 \%$ at $\operatorname{Stn} 3$ ).

\section{DISCUSSION}

The ciliate Ancistrum mytili is common in the gills of bivalves worldwide (Lauckner 1983), and is considered to be more symbiotic than parasitic (Bower et al. 1994, Villalba et al. 1997). Our results support this notion, as the CI was not affected and the tissues of the host were not damaged either. However, the infection could be harmful under unfavorable conditions (Pauley et al. 1966). The high prevalence of A. mytili in the Thermaikos Gulf is similar to that found in mussel cultures in NW Spain (Villalba et al. 1997). The prevalence of the infection was high at the polluted site (Halastra, Stn 2). Previous studies (Kim et al. 1998, Powell et al. 1999) recorded similar high rates in carbohydratepolluted waters. However, Hatzianestis et al. (2001) reported that carbohydrate pollution is more intense at Nea Michaniona (Stn 3). Further experimental surveys are required to examine the relationship between this type of pollution and the prevalence of A. mytili.

The effects of Marteilia refringens/maurini infection include reduction of nutrient assimilation, gonads, and CI (Villalba et al. 1993, 1997, Fuentes et al. 1995). Infection of the mussels in the present study resulted in significant reduction of the $\mathrm{CI}$, while possible damage (lesions) of the digestive epithelium requires further examination. The prevalence of infection of the parasite $M$. refringens/maurini detected in mussels in the present study was similar to that reported in previous studies on cultured Mytilus galloprovincialis from Spain (Fuentes et al. 1995, Villalba et al. 1997), but lower than that previously reported in the Thermaikos Gulf (Virvilis 2003) and in Bretagne (Auffret \& Poder 1985). The prevalence of parasite infection was also high at the polluted site (Halastra, ST2), although Bigas et al. (2000) found no relationship between pollution and the prevalence of parasites.

\section{LITERATURE CITED}

Aguirre MJ (1979) Biología del mejillón (Mytilus edulis) de cultivo de la Ria de Vigo. Bol Inst Esp Oceanogr 5(3): $107-160$

Arsenoudi P, Scouras Z, Chintiroglou CC (2003) First evaluation of Mytilus galloprovincialis Lmk. natural populations in Thermaikos Gulf: structure and distribution. Fresenius Environ Bull 12(11):1384-1393

Auffret M, Poder M (1985) Recherches sur Marteilia maurini, parasite de Mytilus edulis sur les côtes de Bretagne Nord. Rev Trav Inst Pech Marit 47:105-109

Bigas M, Sagristà E, Bozzo MG, Durfort M, Poquet M (2000) Occurrence of heavy metals and protozoan parasites in the mussel, Mytilus galloprovincialis, collected in the western Mediterranean. Ecotoxicol Environ Saf 3:16-21

Bower SM, McGladdery SE, Price IM (1994) Synopsis of infectious diseases and parasites of commercially exploited shellfish. Annu Rev Fish Dis 4:1-199

Ceschia G, Mioni A, Orel G, Giorgetti G (1992) Indagine parassitologica delle mitilicolture del Friuli-Venezia Giulia (Nord-Est Italia). Boll Soc Ital Patol 9:24-36

Comps M, Pichot Y, Papagianni P (1982) Recherche sur Marteilia maurini n. sp. parasite de la moule Mytilus galloprovincialis Lmk. Rev Trav Inst Pech Marit 45:211-214

Da-Ros L, Massignan F (1985) Parasitological investigation on Mytilus galloprovincialis Lmk. bred in the Venice Lagoon (Chioggia Basin). Oebalia 11:809-811

Fuentes J, Villalba A, Zapata C, Alvarez G (1995) Effect of stock and culture environment on infections by Marteilia refringens and Mytilicola intestinalis in the mussel Mytilus galloprovincialis cultured in Galicia (NW Spain). Dis Aquat Org 21:221-226

Fuentes J, López JL, Mosquera E, Vázquez J, Villalba A, Álvarez G (2002) Growth, mortality, pathological conditions and protein expression of Mytilus edulis and M. galloprovincialis crosses cultured in the Ria de Arousa (NW of Spain). Aquaculture 213:233-251

Hatzianestis J, Sklivagou E, Georgakopoulou E (2001) Hydrocarbons, pesticides and PCBs in sediments from Thermaikos Gulf, Greece. Fresenius Environ Bull 10:63-68

Kim Y, Powell EN, Wade TL, Presley BJ, Sericano J (1998) 
Parasites of sentinel bivalves in the NOAA Status and Trends Program: distribution and relationship to contaminant body burden. Mar Pollut Bull 37:45-55

Lauckner G (1983) Diseases of Mollusca: Bivalvia. In: Kinne O (ed) Diseases of marine animals, Vol II. Introduction, Bivalvia to Scaphopoda. Biologische Anstalt Helgoland, Hamburg, p 477-879

Martoja R, Martoja M (1967) Initiation aux techniques de l'histologie animale. Masson, Paris

Pauley GB, Sparks AK, Chew KK, Rabbins EJ (1966) Infection in Pacific coast mollusks by thigmotrichid ciliates. Proc Natl Shellfish Assoc 56:8

Powell EN, Barber RD, Kennicutt MC II, Ford SE (1999) Influence of parasitism in controlling the health, reproduction and PAH body burden of petroleum seep mussels. DeepSea Res 46:2053-2078

Rayyan A, Chintiroglou CC (2003) Steinhausia mytilovum in cultured mussels Mytilus galloprovincialis in the Ther-

Editorial responsibility: Albert K. Sparks,

Seattle, Washington, USA maikos Gulf (northern Aegean Sea, Greece). Dis Aquat Org 57:271-273

Robledo JAF, Santarém MM, Figueras A (1994) Parasite loads of rafted blue mussels (Mytilus galloprovincialis) in Spain with special reference to the copepod Mytilicola intestinalis. Aquaculture 127:287-302

Villalba A, Mourelle SG, Carballal MJ, Lopez C (1993) Effects of infection by the protistan parasite Marteilia refringens on the reproduction of cultured mussels Mytilus galloprovincialis in Galicia (NW Spain). Dis Aquat Org 17: 205-213

Villalba A, Mourelle SG, Carballal MJ, Lopez C (1997) Symbionts and diseases of farmed mussel Mytilus galloprovincialis throughout the culture process in the Rias of Galicia (NW Spain). Dis Aquat Org 31:127-139

Virvilis C, Angelidis P, Photis G (2003) Presence of the parasite Marteilia sp. in the shellfish of the Thermaikos gulf in northern Greece. Bull Eur Assoc Fish Pathol 23:157-162

Submitted: April 27, 2005; Accepted: February 16, 2006 Proofs received from author(s) June 16, 2006 